\title{
Financial Infrastructure of Investments Flows between Developed and Developing Countries
}

\author{
Krivopal Mikhail Yurievch, Krivelevich Maksim Evseevich, Likhacheva Valentina Vladimirovna, Maksimova \\ Anastasia Alekseyevna \\ «Finance\&Credit» Department \\ Far East Federal University \\ Vladivostok, Russia \\ krivopal@mail.ru
}

\begin{abstract}
This article describes the main areas of foreign investments and the problem of the under-utilization of capacities of developing countries due to incorrect interpretation of the stakeholders' behavior. Four hypotheses were studied in this article and, as a result, there were formed suggestions for solving the underlying problem. Research proves that it is necessary to encourage public-private partnerships, to raise capital needed for the development of regional projects. Summing up all mentioned above, it could be suggested that foreign direct investment is a very important financial indicator in the 21 st century. While the need in foreign investments sharply arises, more and more problems appear for the developing countries, looking forward to attracting investors' attention. Initially, investors mostly tend to profit, but the fear of not getting it at all, the loss of their funds, stops investors from putting their money in the developing economies.
\end{abstract}

Keywords-Foreign Direct Investments; Behavioral Economy; Risk-Return Strategy; Developing Countries; Developed Countries

\section{INTRODUCTION}

Nowadays there is rapid spread of means of communication and information technologies that influence economic activity [1]. Faster crumbling national barriers and opening up new avenues of trade and investment in the financial markets mean that globalization becomes commonplace. One of the major trends in globalization is foreign direct investment (FDI) [2]. Countries are trying to increase its appeal to attract them. Foreign direct investment is a form of participation of the capital of investors in the recipient country, which use it to implement important projects and involves new technology and innovation systems [3]. It is obvious that many scientists find negative components of foreign investment, such as inherent risk, or the possibility of corruption in the government-recipient, but it always displayed a single result - without foreign direct investment, the progress in the country slows down, or disappears altogether [4].

A sufficient number of prerequisites for the growing importance of globalization and FDI flows can be selected [5]. The first will be the most obvious and important - the need to create a competitive advantage in manufacturing technology. Every country goes through the stage of development, but its own resources for this process, as well as existing technologies in the country, are not always enough [6]. The world's progress is based on the cross-country competition, i.e., each country, developing production technology (which is possible in a full way only with the existence of FDI), has contributed to the progress and, consequently, improves its position in the global arena.

The next prerequisite is a low cost (for example, in China). Generally, industry producing is placed where they can operate efficiently at the lowest cost of the manufacturing process. Investors prefer countries where restrictions on production are as little as possible [7]. The processes of business units functioning are considered by Glukhov and etc [8-10].

However, there are prerequisites, often pointing to the irrationality of investing. These assumptions include differences in the institutional system of the economy in both developed and developing countries. The level of relations among the state, the legislative framework and financial institutions is different for developed and developing countries. On this basis, there is a model of investment in which developed countries are investing in developing countries (where there are fewer restrictions and more profit), and are developing into developed countries (where risks are reduced)

Also, various stakeholders, making cross-country investments, have totally wrong behavioral aspects, incentives and constraints of each other. In this case, the phenomenon of false demand for risk [11] and investment appears.

At this moment, this question is quite relevant in connection with the economic situation in the world. There are several groups of authors who work with this theme:

1. Authors are considering aspects of investment and the main problems and perspectives from developed countries. It is considered in general and in connection with the specifics of this article, for example, in Australia [12, 13].

2. Allocating the benefits of investing in developing countries, especially in Russia, is an object in this article [14, $15,16]$.

3. Authors, conducting research on specific countries, where they indicate the role and effects of foreign direct investment. It shows the specific directions of the FDI and its 
influence in China and India [17], Poland [18], BRIC countries [19].

\section{LITERATURE REVIEW}

For the first time, the concept of investment and investment bank was mentioned in early 1776 by Adam Smith [20], but the investment as a factor, influencing the economic development, was firstly mentioned by John Keynes. He explained investments as a current growth of capital values of property as a result of industrial activity for the certain period and was closely intertwined with the concept of international trade.

Initially, there were several theories of international trade [18]. First, the theory of comparative advantage of Ricardo appeared, where he argues that each country specializes in the production of those goods for which its labor costs are lower compared to other industries, even if the production abroad would be more beneficial. Then everything which was turned to Herscher-Ohlin theory explains that countries export goods from sectors where there is an excess of the product, and foreign investment, in turn, will be sent to those industries where the relative lack of resources is observed.

But this theory has been refuted in the study of Leontiev. In his "Paradox" he explored America of the 50-70s and revealed that, despite the abundance of capital, the country was exporting intellectual products. Then, when in the developed economies the wages started to grow, a system of moving production to other countries because of cheaper resources appeared. And now economies move to the new level of attraction of capital, which is described in the model of Paul Krugman, "center - periphery", which revealed that some centers in the country create innovations, collecting resources from the periphery, and after creation, innovation spreads into the periphery. That means that system is selfregulating, and an important prerequisite for the creation of "centers" is the technical potential of the territory.

Now the main competitive advantage will be the scientific basis [21], the ability to create and implement new technologies. Funding will flock to the places where such opportunities are created. Initially developed countries have better conditions for the creation of such opportunities, but the return on capital is higher in developing countries, and if these countries will be able to develop the scientific and technical component, to provide highly qualified personnel, foreign investors will prefer to invest in developing countries [22].

The behavioral abnormalities vastly contribute to decisionmaking of the investor side. This issue was investigated by Daniel Kahneman in prospect theory, which describes the various stakeholder choices in possible solutions associated with risks in different conditions. It is particularly important to take into account features of behavioral abnormalities when considering the institutional systems in developing economies.

\section{RESEARCH METHODOLOGY}

The authors have identified four groups of prerequisites for the development of globalization and foreign investment. The first is the need to create and produce competitive advantages in production technology [23]. Next is a low cost price for the transfer of production to other countries. Third is the difference in the institutional system of the economy in both developed and developing countries. And, finally, stakeholders have wrong behavioral aspects, incentives and constraints of each other. The need for innovation stands out separately as a prerequisite [6], but not only innovations provide a competitive advantage, but the whole complex, so one has to identify a broader meaning as a prerequisite.

Other authors define the presence of the resource base and cheap labor as a second prerequisite [16]; the indicators that the authors have identified as a low cost. Much attention is paid to the fact that in developing countries, such as Russia [14] or China [5], the state does not pay due attention to the development of regions, and does not follow the decrease in corruption [7], while in developed countries, corruption is minimized. But here and there, there are contradictions, as bribable country prefers to invest in countries with high levels of corruption [24]. This model highlights the incorrect premise of behavioral aspects, especially connected with the understanding the risk strategy [11], which in turn may be due to misinterpretation of reduced investment in the country.

On the basis of these prerequisites the main problem arises in foreign direct investment, it is incomplete use of the potential utility maximization [25] in terms of attracting investment by developing countries due to lack of a multicriteria model taking into account behavioral characteristics in the process of determining strategies based on the concept of risk-return.

Due to the problems, it turns out that the cross-country specialization deepened with the production of certain groups of goods to the production of individual parts. And the rate of acceleration of the level of development of cross-country communications reaches extremely high levels [26]. But the barriers between developing and developed countries, in terms of more effective cooperation, still quite significant. These barriers are the difference between the interest rates, the cost of investment resources, taking into account the free movement of capital in centers with a high yield [27]. The question is precisely that in developing countries there is a need in investment, equity financing, where part of the risk takes on a country-investor and the question is how to attract investors.

Next consequence is that a huge amount of resources in developing economies are either not involved in the global turnover, or inefficiently mined because of heavy losses, the lack of new technologies and funding from developed countries. This is stagnation, when the resource base of the country is irrationally used. This problem exists even in developed countries (for example, Australia's coal), but due to enough amount of the investment this problem can be solved [28].

One of the consequences, on the contrary, can serve as a "leak" of a large number of resources in the developed economies, where the yield of the normal functioning is decreased to the minimum limits so that it leads to a growing number of economic bubbles, strains and crises. It came to the situation where there are specifically arranged fluctuations in 
the market to increase the profitability of a minimum level of $2-3 \%$. For comparison, in developing countries the rate of return is much higher, but there is a shortage of financial resources.

\section{MODEL AND RESUlts ANALYSIS}

On the base of previous information, the authors formed four hypotheses.

Hypothesis 1 - The system of relations that should be built between developed and developing economies in terms of investment should has a multicriteria character. Conditions of the functioning of economies and the external environment vary with fast speed and due to the increased frequency of changes in the environment it needs to be introduced a new model of relations. This model should include such effects, through which it will be self-regulating.

Hypothesis 2 - The model must be stabilized independently, autonomously adapted to the changing of external environment or, at a minimum, it must provide the company with timely detection of the deformation and overcome it, preventing the negative effects. The internal stabilization mechanisms need to be included in the model in order to minimize losses.

Hypothesis 3 - Multicriteria model among other things must ensure constant readiness for potential possibilities. It is necessary to provide the financial base that can be used in order to catch the possibility and implement it [29].

Hypothesis 4 - For the successful implementation of the hypotheses, it is necessary to improve the institutional system and financial instruments [30]. There is the need for close cooperation of the government of a developing economy, enterprises that need an investment, the government of the country-investor and its companies. In this case, the clear separation desired between the initiator (state or company) and impact strength (sufficient stimulation, a clear distinction between the obligations or public-private partnerships, joint projects and sharing of risks).

Applying these hypotheses, one can put forward the following proposals to solve this problem.

For the most part, the government of a developing economy alone or with businesses that need to invested funds [31] advocate for the creation of programs of investment in emerging economies. Discussions and agreements on proposals and interests of investors from developed countries and their governments can imply taking certain measures to stimulate investment [32].

There are two ways to implement them: either by the government forces or on the basis of self-regulating market relations company needing investment, independently participating in programs designed to attract them. By this method of implementation, there is the development of competition, when companies try as much as possible to participate in such programs to take a greater share of the market [33], as well as the principle of public-private partnerships (PPP). Table 1 shows the model and possible variations of the PPP.
TABLE I THE MODEL OF THE PUBLIC-PRIVATE PARTNERSHIPS

\begin{tabular}{|l|c|c|c|}
\hline & Government & Business & PPP \\
\hline Government & Strategy A & Strategy B & Strategy C \\
\hline Market & Strategy D & Strategy E & Strategy F \\
\hline PPP & Strategy G & Strategy H & Strategy J \\
\hline
\end{tabular}

Figure Strategy A - The government of a developing economy creates conditions for attracting foreign investments, and then the state makes its corporations use of these opportunities to attract investment;

Strategy B - The government creates conditions, corporations themselves that tend to use these opportunities;

Strategy $\mathrm{C}$ - The government creates conditions and then government and corporation, joint projects;

Strategy D - Market encourages companies to create a program, the state is forcing companies to participate;

Strategy E - Companies create conditions that companies should be involved in programs;

Strategy F - Companies create conditions and then joint projects with government;

Strategy G - State and corporations jointly come up with the program, the state corporation makes use of opportunities;

Strategy $\mathrm{H}$ - The state and the corporation jointly come up with programs that corporations use;

Strategy J - The state and the corporation jointly come up with a program, then both, government and corporation, joint projects.

As a result, strategy $\mathrm{J}$ is the most successful, as in both sides the advantages appear. For the state they are: attracting a private capital for the construction of public facilities; involvement of management and intellectual capital from the private sector. For the company they are: a risk sharing with the state; guarantees from the government [34]; administrative and political assistance from the state in the implementation of the project.

It should also be clarified that in the process of publicprivate partnership an important indicator should be considered - how many dollars of foreign investment accounted for one dollar of government investment. Today, emerging economies are crucial to maximize the amount of attracted investments per dollar of government investments. That can be estimated as the effectiveness of public-private partnerships, because foreign investors, in the first place, invest heavily in the area where not only the company is involved, but also the government is [35].

The next group of suggestions is the suggestions in the sphere of the direct involvement of the state in stimulating investment processes in the region. There is the systematic implementation of the trilateral policy with the purpose of maximizing the multiplier of government spending in the context of attracting financial resources to the regions. Firstly, it is necessary to attract foreign investment in the non-profit sphere of infrastructure projects in the region with a guarantee of a certain level of profitability. It is necessary to use the 
effect of financial leverage in the form of implicit lending of regional economy, as well as improving the investment climate through the direct participation of the foreign investor and its adaptation to local conditions [36]. Secondly, one must adjust all of the planned investment expenditure in the region by attracting the additional investment, comparing to one dollar of government investment. Thirdly, one should consolidate the compulsory sale of the state share after passing certain stages of the investment cycle in order to create an appropriate investment proposal [37] in the form of certain financial products targeted at specific investors through appropriate investment institutions of the international financial market from the very beginning of the project. For example, in 2012, the one unit of public investment in the region accounted for one unit of investment by domestic private sources in the region, one unit by investment by parent outside organizations, and only 0.08 units of foreign investment.

\section{FORMATION OF CROSS-BORDER FINANCIAL INFRASTRUCTURE FOR THE DEVELOPMENT OF ENTREPRENEURSHIP}

Before setting the problem, outlining the main conceptual apparatus, let us consider the financial market as an alternative mechanism for mobilizing resources in the process of incorporation of business units. There is a lack of systemcatching actors in the roles of the complete redistribution of risks and returns. Informational efficiency of the financial market, according to the methodology of Fame, can be viewed as a necessary and sufficient condition for a rational allocation of scarce resources to optimality criterion with risk-return position, in the context of its ability to immediately and fully reflect the newly incoming information in the price of the asset. Using the method of modelling, interpreting neopositivist schools admit the possibility of existence of the market where the above-mentioned condition is taking place. Then, if it is carried out not in full, one must admit the existence of certain obstacles to achieve the status of full market information efficiency. It is the existence of the reasons that is designated as a research problem; let us define them as a deformations (pricing).

Using the Scopus database, the authors selected articles of leading scientists to study the process of the financial markets associated with the formation of the financial infrastructure for the development of entrepreneurship. There is significant contribution to the scientific development of the topic made by representatives of classical and neo-classical school, the monetarists (neutral interest rate, pre-programmed selfregulatory processes in the RF). The maximum proceeds from rationality assumptions and the absolute efficiency of information allows us to speak about the relative determinism processes in the financial market as autonomous endogenous mechanisms, creating investments in the economy, do not possess as much as an independent dynamic-regulatory capacity.

In the opposite vein, the developed idea of the representatives of the Cambridge school of A. Marshall, Pigou, Keynes offered hypothesis which is a directly dependent primary desire of borrowers to deliver savings to the financial market in the theory of liquidity preference, and to reveal the multiplier effect of the autonomous factors determining the aggregate demand in the economy, thereby laying the foundation for modelling relationships in the financial and real sectors of the economy.

The modern approach to the financial market was formed after the description of portfolio theory H. Markowitz and a capital asset pricing model of William Sharpe. When the nature of the stock market became clearer in terms of the concepts of the information risk-return box, there are no financial intermediaries in the form of banks and studies. $\mathrm{J}$. Akerloff considered problems of adverse selection and misconduct to propose a new subject of financial intermediaries, which, because of information asymmetry and the irrationality of the factors put forward by representatives of the institutional and behavioural economics branch, fulfil "the role of dealers in the market for second-hand vehicles" and ensure efficient investment in the economy.

The purpose of this study is also to develop theoretical models based on different economic schools of recommendations to strengthen the multiplier effect in the system, "the financial market - the real economy". The main objective in this case is reduced determination of the main problems and prospects of development of regional financial markets. The object of study - the financial market in the region - a system of relations that satisfy the financial interests of the regional primary borrowers and lenders, regardless of geography and ethnicity mediators - the backbone subjects of the regional financial market. The research question is formed: what is the financial infrastructure of entrepreneurship and how to ensure its effective functioning? The author offers an expanded interpretation of the boundaries and scope of consideration of the concept of the regional financial market based on the principle of serving the interests of the derivative of the primary lenders and borrowers in the region. Based on the research of Academician Manaker, the authors identified the main problems and possible directions for their resolution in the context of the prospects for the development of the regional financial market.

The problem of development is seen as a set of endogenous and exogenous factors, opposing the implementation of the essential functions of the object of study, which largely reflected in the lack of incentives for the production of key financial products. The uniqueness of a financial product is its ability to simultaneously satisfy the interests of both the primary borrowers and lenders in the primary economy. Compared with the existing economic potential volume of investment demand, there is a shortage on the supply side of capital within the region and the relevant financial market instruments to attract investment from outside the region is practically not formed. In the analysis of the financial markets, among other things, it is important to interpret that affects the ability (factors and tools) and desire (incentives) of financial intermediaries to attract and allocate capital in the region.

First, it is important to highlight the crucial role of financial infrastructure for the development of entrepreneurship, the nature of which lies in its ability to 
overcome information asymmetry in as large scale. Western scholars generally emphasize the need to ensure access to external sources of financing for business units.

Let us allocate the main thesis, implying that it is critical to establish and maintain rating tools for small and medium-sized businesses. Formed mechanism is the core of the financial infrastructure for the development of entrepreneurship. One can offer several models for achieving this goal. For example, the stock exchange for small enterprises can successfully cope with this mission. Another approach is to create a rating system indirectly, by actively stimulating the development of factoring companies. Analyzing the cost of debt repayment for various businesses can freely assess the degree of confidence in them by their financial counterparts. The development of regional financial market as a derivative system serves the interests of the primary lenders and borrowers in the region is the basis for creating the financial infrastructure for the development of entrepreneurship.

The financial infrastructure consists of two parts, namely the mechanisms instrument rating, allowing overcoming the information asymmetry that allows companies and the business units to commercialize the level of confidence in himself. Another important mechanism of the financial infrastructure is the ability of systemically important entities of financial market in the region, together with entrepreneurs to shape financial products for investors thus attracting financial resources for the financing of the business processes.

Besides the obvious advantages to the business itself, the ability to commercialize the level of confidence in their own businesses through access to more favorable conditions to attract funding, forcing entrepreneurs to create more transparent business processes, will facilitate the state control and will undoubtedly increase the tax collection.

Further studies may be associated with the release of more specific tools and specific mechanisms to ensure that rating, as well as the specifications of financial products most suitable for entrepreneurial agents in the initial period of its formation.

\section{CONCLUSIONS}

Summing up the information mentioned above, it can be suggested that foreign direct investment is a very important financial indicator in the 21 st century. While the need in foreign investments sharply arises, more and more problems appear for the developing countries looking forward to attracting investors attention. Initially, investors mostly tend to profit, but the fear of not getting it at all, the loss of their funds, stops investors from putting their money in the developing economies. It is important to take into account the level of development of business relations. That is the reason for a lack of investment in developing countries. Having analyzed the basic premises of foreign direct investment, the authors identified the main problem-solving, as well as the necessity of introducing these decisions in the economy. In addition, it is important to know the characteristics of connections between different markets and developing countries features. All the options proposed may help to solve the problem of irrational investment and, therefore, to develop the economies of developing countries.

\section{References}

[1] S. Chetty, M. Johanson, O.M. Martin, Speed of internationalization, pp. Conceptualization, measurement and validation. Journal of World Business, 49, pp. 633-650, 2014.

[2] , C. Lessmannn, Foreign direct investment and regional inequality, pp. A panel data analysis. China Economic Review, 24, pp. 129-140, 2013.

[3] X. Liu, I.R. Hodgkinson and F. Chuang, Foreign competition, domestic knowledge base and innovation activities, pp. Evidence from Chinese high-tech industries. Research Policy, 43, pp. 414-422, 2014.

[4] O. Kuzmina, N. Volchkova, T. Zueva, Foreign direct investment and governance quality in Russia. Journal of Comparative Economics, 2014.

[5] M.A. Almfraji, M.K. Almsafir, Foreign Direct Investment and Economic Growth Literature Review from 1994 to 2012. Social and Behavioral Sciences, 129, pp. 206-213, 2014.

[6] V.G.R. Chandran, C.F. Tang, The impacts of transport energy consumption, foreign direct investment and income on $\mathrm{CO} 2$ emissions in ASEAN-5 economies. Renewable and Sustainable Energy Reviews, 24, pp. 445-453, 2013.

[7] W.W. Olney, A race to the bottom? Employment protection and foreign direct investment. Journal of International Economics, 91, pp. 191-203, 2013.

[8] V. Glukhov, Z. Lialina, V. Ostanin, Theoretical basic concepts of interaction of money and finances. Middle East Journal of Scientific Research 17 (1), pp. 6-10, 2013.

[9] V. Glukhov, E. Glukhov, Z. Lialina, V. Ostanin, Y. Rozhkov, Social function of small business taxes in Russia. Asian Social Science 11(19), pp. 247-256, 2015.

[10] V. Glukhov, Z. Lialina, V. Ostanin, Social significance and the subject matter of taxes in life of modern society. Source of the Document Life Science Journal 11 (10 SPEC. ISSUE), 52, pp. 292-295, 2014.

[11] J. Zhang, L. Hou, 2014, Financial structure, productivity, and risk of foreign direct investment. Journal of Comparative Economics, 42, pp. 652-669.

[12] R. Gupta, G.D. Donleavy, Benefits of diversifying investments into emerging markets with time-varying correlations, pp. An Australian perspective. Journal of Multinational Financial Management, 19, pp. 160-177, 2009.

[13] A.V. Mishra, Foreign ownership in Australian firms. Research in International Business and Finance, 28, pp. 1-18, 2013.

[14] S., P. Ledyaeva, Karhunen, R. Kosonen, Birds of a feather, pp. Evidence on commonality of corruption and democracy in the origin and location of foreign investment in Russian regions. European Journal of Political Economy, 32, pp. 1-25, 2013.

[15] E. Kropatcheva, Russian foreign policy in the realm of European security through the lens of neoclassical realism. Journal of Eurasian Studies, 3, pp. 30-40, 2012.

[16] S.M. Hashim, Power-loss or power-transition? Assessing the limits of using the energy sector in reviving Russia's geopolitical stature. Communist and Post-Communist Studies, 43, pp. 263-274, 2010.

[17] V. Vivoda, Determinants of foreign direct investment in the mining sector in Asia, pp. A comparison between China and India. Resources Policy, 36, pp. 49-15, 2011.

[18] Kowalewski, O. and M.J. Radlo. Determinants of foreign direct investment and entry modes of Polish multinational enterprises, pp. A new perspective on internationalization. Communist and PostCommunist Studies, xxx, pp. 1-10, 2014.

[19] R.A. Ratti, J.L. Vespignani, Crude oil prices and liquidity, the BRIC and G3 countries. Energy Economics, 39, pp. 28-38, 2013.

[20] A. Smith, An inquiry the nature and causes of the wealth of nations. London, 1776.

[21] M. Ye, E. Hutson, C. Muckley, Exchange rate regimes and foreign exchange exposure, pp. The case of emerging market firms. Emerging Markets Review, 21L, pp. 156-182, 2014.

[22] C.F. Tang, C.Y. Yip and I. Ozturk, The determinants of foreign direct investment in Malaysia, pp. A case for electrical and electronic industry. Economic Modelling, 43, pp. 287-292, 2014. 
[23] S. Anwar, L.P. Nguyen, Is foreign direct investment productive? A case study of the regions of Vietnam. Journal of Business Research, 67, pp. 1376-1387, 2014.

[24] M.S. Delgado, N. McCloud, S.C. Kumbhakar, A Generalized Empirical Model of Corruption, Foreign Direct Investment, and Growth. Journal of Macroeconomics. , 2014

[25] M.W.L. Chan, K. Hou, X. Li, D.C. Mountain, Foreign direct investment and its determinants, pp. A regional panel causality analysis. The Quarterly Review of Economics and Finance, 54, pp. 579-589, 2014.

[26] L. Votintseva, D. Sozaeva, M. Andreeva, Innovation policy in the context of budget mechanism reformation, pp. Goals outline and the tools required for successful implementation. International Journal of Economics and Financial Issues, 5(4), pp. 1024-1028, 2015.

[27] N. Kuznetsova, L. Votinseva, Document The modern system of regulation in the sphere of financial intermediation, pp. Methodological approaches and solutions. Biosciences Biotechnology Research Asia 11, pp. 345-355, 2014.

[28] J. West, Japanese investment in Australian coal assets through the demise of concessional financing. Energy Policy, 52, pp. 513-521, 2013.

[29] L. Wang, A. Nagapetyan, E. Lutsenko, V. Pakhmutov, Theory and methodology for financial infrastructure of foreign direct investment in developing countries, pp. The BRICS case. International Review of Management and Marketing 6(1), pp. 179-183, 2016.

[30] A. Nagapetyan, E. Rubinshtein, Comparison of the positive and negative risk's indices as a tool for portfolio management. Actual Problems of Economics 7, 2016.
[31] A. Nagapetyan, E. Skaletckii, J. Khamdamov, Development of Portfolio Theory, pp. Pricing Deformations and Autonomous Self-regulation of the Financial Market. Mediterranean Journal of Social Science 6(7), pp. 237-241, 2015.

[32] M. Giofre, Domestic investor protection and foreign portfolio investment. Journal of Banking \& Finance, 46, pp. 355-371, 2014.

[33] C. Thapa, S.S. Poshakwale, Country-specific equity market characteristics and foreign equity portfolio allocation. Journal of International Money and Finance, 31, pp. 189-211, 2012.

[34] A.V. Mishra, R.A. Ratti, Governance, monitoring and foreign investment in Chinese companies. Emerging Markets Review, 12, pp. 171-188, 2011.

[35] J. Chou, N. Zaiats, B. Zhang, Does auditor choice matter to foreign investors? Evidence from foreign mutual funds worldwide. Journal of Banking \& Finance, 46, pp. 1-20, 2014.

[36] B.Y. Aw, Y. Lee, A model of demand, productivity and foreign location decision among Taiwanese firms. Journal of International Economics, 92, pp. 304-316. , 2014

[37] Y. Kandogan, The effect of foreign trade and investment liberalization on spatial concentration of economic activity. International Business Review, 23, pp. 648-659, 2014. 